Przemysław Waingertner

(Uniwersytet Łódzki

Wydział Filozoficzno-Historyczny

Katedra Historii Polski Najnowszej)

\title{
JERZEGO GIEDROYCIA IDEA ULB - GENEZA, ZAŁOŻENIA, PRÓBY REALIZACJI. ZARYS PROBLEMATYKI
}

J

erzy Giedroyc - nie sposób było pozostać obojętnym wobec głoszonych przez niego poglądów i podejmowanych działań. W Polsce międzywojennej, określając się mianem konserwatysty i piłsudczyka, był krytykowany zarówno przez zachowawców (zarzucających mu „,socjalizowanie”), jak i adherentów Marszałka (oskarżających go o nieuzasadnione poddawanie w wątpliwość autorytetu Jego następców). Atakowali go również socjaliści i narodowcy, odrzucając tezy jego publicystyki. Po II wojnie światowej - wbrew własnym intencjom - podzielił polską emigrację, ale także antykomunistyczną opozycję w kraju. Jedni komplementowali go jako prawdziwego męża stanu i wizjonera, ukazującego perspektywy dla niepodległej i demokratycznej przyszłości Polski i całej Europy Wschodniej, a zarazem myśliciela poważnie traktującego znane przysłowie o historii jako „nauczycielce życia”. Inni krytykowali go za polityczną naiwność - złudną wiarę w możliwość liberalizacji systemu komunistycznego i słabość wobec „nawróconych komunistów”. Dla władz tzw. Polski Ludowej był ,agentem CIA”, tymczasem dla Amerykanów, współpracujących ze środowiskami polskiej emigracji, pozostał „niepokornym Polakiem”, pragnącym zachować niezależność finansową i polityczną. Po upadku Związku Sowieckiego i odzyskaniu przez Polskę niepodległości nadal budził kontrowersje z racji podejmowanej przez niego krytyki elit politycznych Trzeciej Rzeczypospolitej.

Jerzy Giedroyc urodził się 27 VII 1906 r. w Mińsku. Przyszedł na świat jako potomek spolonizowanego litewskiego rodu. Dzieciństwo spędził w Rosji - w Mińsku, Moskwie i Petersburgu. Po odzyskaniu przez Rzeczpospolitą niepodległości Giedroyciowie - jak wiele innych polskich rodzin, rozsianych po najdalszych zakątkach dawnego imperium carskiego - przenieśli się do odrodzonej ojczyzny. Osiedli w stolicy, gdzie Jerzy skończył w 1924 r. prestiżowe gimnazjum im. Jana Zamoyskiego, a następnie rozpoczął studia prawnicze na Uniwersytecie Warszawskim. Po ich ukończeniu studiował jeszcze w latach 1930-1931 historię. Równocześnie podjął pracę zarobkową - najpierw na stanowisku referenta 
prasowego i parlamentarnego w Ministerstwie Rolnictwa, następnie jako samodzielny naczelnik wydziału prezydialnego w Ministerstwie Przemysłu i Handlu ${ }^{1}$.

Jednak to nie kariera urzędnicza, ale działalność społeczno-polityczna - przede wszystkim dziennikarska i publicystyczna - okazała się życiowym wyborem J. Giedroycia. Jeszcze podczas studiów udzielał się w akademickim życiu organizacyjnym - prezesował korporacji „Patria” i Kołu Międzykorporacyjnemu w Warszawie oraz pracował w dziale zagranicznym Naczelnego Komitetu Polskiego Związku Młodzieży Akademickiej. Szefował też redakcji „Dnia Akademickiego” (dodatku do pisma „Dzień Polski”). Stał się jednym z liderów i ideologów konserwatywnej i propiłsudczykowskiej organizacji studenckiej Myśl Mocarstwowa. Należał również do ścisłego grona kierowniczego innych zachowawczych struktur - Związku Pracy Mocarstwowej i Związku Drużyn Ludowych Mocarstwowej Polski. Zadbał także o trybunę dla upowszechniania bliskich mu koncepcji, przekształcając w 1931 r. „Dzień Akademicki” w samodzielny dwutygodnik „Bunt Młodych”, który następnie zmienił nazwę na „Polityka. Dawniej »Bunt Młodych «". Zdołał zebrać wokół tego pisma najlepsze pióra młodego pokolenia polskiego dziennikarstwa. Dla „Buntu Młodych”, a później „Polityki” pisali wybitni młodzi konserwatywni publicyści m.in.: Ksawery i Mieczysław Pruszyńscy, Stefan Kisielewski oraz Aleksander i Adolf Bocheńscy².

W 1938 r. ukazał się drukiem - zatytułowany cokolwiek patetycznie - program środowiska skupionego wokół „Polityki”: Idea Polski imperialnej. W dokumencie tym odrzucano koncepcję polityki jako klasycznej gry partii politycznych - mających stanowić wcielenie demagogii i partykularyzmu - dla których głównym celem miało być jedynie zdobycie władzy i zaspokajanie ambicji przywódców, a instrumentem działania populizm, żerujący na naiwności społeczeństwa. Prawdziwa praca państwowotwórcza, według autorów Idei Polski imperialnej, wymagała konsekwentnego kształtowania opinii mas, nie zaś ulegania jej wahaniom. Działalności politycznej nie wolno było przy tym oddzielać od troski o najwyższe dobro - państwo polskie 3 .

Trudno określić jednoznacznie poglądy samego J. Giedroycia z tego okresu. Był konserwatystą, który nie odżegnywał się od wprowadzania ograniczonego, prosocjalnego ustawodawstwa w imię wzmocnienia państwa i zarzucał staremu pokoleniu zachowawców klasowy egoizm. Był demokratą gotowym poświęcić w imię „mniejszego zła” prawa obywatelskie na ołtarzu politycznej stabilizacji i doskonalenia ustroju. Jak wspominał później:

${ }^{1}$ J. Giedroyc, Autobiografia na cztery ręce, oprac. i posłowie K. Pomian, Warszawa 1994, s. 9-25.

${ }^{2}$ Poglądy środowiska „Myśli Mocarstwowej” i pism „Bunt Młodych” oraz „Polityka. Dawniej „Bunt Młodych«” zob. Zamiary, przestrogi, nadzieje, „Bunt Młodych”, „Polityka” 1931-1939. Wybór publicystyki, oprac. J. Jaruzelski, R. Habielski, Lublin 2008, passim; M. Król, Style politycznego myślenia. Wokót „Buntu Młodych” i „Polityki”, Paryż 1979, passim.

${ }^{3}$ P. Waingertner, Redaktor, „Myśl.pl”, wiosna 2009, nr 13, s. 59-60. 
Gdy usprawiedliwiałem działania niekonstytucyjne czy sam usiłowałem je podejmować, miałem na widoku naprawę państwa, uczynienie go lepszym, bardziej sprawiedliwym, bardziej logicznym. Dlatego np. uważałem Brześć za uzasadniony. Centrolew był realnym zagrożeniem, zamierzał robić w Polsce rewolucję... Internowanie działaczy Centrolewu było w tych warunkach aktem obrony koniecznej, chociaż gwałciło immunitet poselski i było nielegalne, leżało $w$ interesie państwa ${ }^{4}$.

Był wreszcie J. Giedroyc zwolennikiem Polski suwerennej, który jednak w imię ratowania narodowej substancji i praktykowania „realpolitik” opowiadał się u schyłku lat trzydziestych za daleko idącym kompromisem z Trzecią Rzeszą. Najcelniej charakteryzowało jego postawę ideową określenie „państwowiec”, którego często używali dla zdefiniowania swego usytuowania na politycznej mapie międzywojennej Rzeczypospolitej piłsudczycy, podkreślając, że tradycyjne podziały ideologiczne straciły aktualność, a priorytetem dla obywateli niepodległej Polski powinno być wzmacnianie państwa przy użyciu wszelkich środków - zarówno postulowanych przez prawicę, jak i lewicę.

Po wybuchu II wojny światowej J. Giedroyc, jako wysoki urzędnik Ministerstwa Przemysłu i Handlu, został ewakuowany do Rumunii, gdzie pełnił funkcję sekretarza Rogera Raczyńskiego, wykonującego obowiązki ambasadora Rzeczypospolitej Polskiej w Bukareszcie. Po likwidacji ambasady został kierownikiem Wydziału Polskiego przy poselstwie chilijskim w stolicy Rumunii, a zarazem współpracownikiem poselstwa angielskiego, reprezentującego interesy polskie wobec władz rumuńskich. Wiosną 1941 r. został ewakuowany do Stambułu. Tam zgłosił się do służby wojskowej, a następnie wyjechał na Bliski Wschód do Palestyny, gdzie wstąpił do Samodzielnej Brygady Strzelców Karpackich. W jej szeregach uczestniczył później w kampanii libijskiej i w walkach o Tobruk ${ }^{5}$. Jednak ponownie upomniała się o niego publicystyka i świat polityki. Jego przełożeni wiedzieli, że mimo wojennego czasu nie karabinem, lecz piórem mógłby zrobić dla sprawy polskiej znacznie więcej niż zwykły żołnierz. W latach 1943-1944 kierował zatem Wydziałem Czasopism i Wydawnictw Wojskowych Biura Propagandy Drugiego Korpusu Polskiego. Z kolei w latach 1944-1945 pracował w Centrum Wyszkolenia Broni Pancernej w Gallipoli. Ostatecznie w 1945 r. objął stanowisko dyrektora Departamentu Europejskiego Ministerstwa Informacji Rządu Rzeczypospolitej Polskiej w Londynie ${ }^{6}$.

W 1946 r. J. Giedroyc zdecydował się na ryzykowny krok, który - jak się później okazało - zdecydował o całym jego przyszłym życiu. Dzięki finansowej i organizacyjnej pomocy Drugiego Korpusu i kredytowi zaciągniętemu w tzw.

${ }^{4}$ J. Giedroyc, Autobiografia na cztery..., s. 41-42.

${ }^{5}$ A. S. Kowalczyk, Jerzy Giedroyc w Bukareszcie (1939-1940), „Zeszyty Historyczne”, [Paryż] 2001, z. 136, s. 3-41.

${ }^{6}$ K. Jeleński, O „Kulturze” dla Francuzów, [w:] J. Giedroyc, K. A. Jeleński, Listy 1950-1987, wybór, oprac. i wstęp W. Karpiński, Warszawa 1995, s. 493. 
Funduszu Żołnierskim, założył w Rzymie wydawnictwo książkowe, któremu nadał nazwę Instytutu Literackiego. Rozpoczął też natychmiast druk nowego pisma - „Kultury”. Pierwszy numer periodyku ukazał się już w czerwcu 1947 r. Następnie (za zgodą generała Władysława Andersa) jego redakcja została przeniesiona do Francji. Początkowo zainstalowano ją w miejscu symbolicznym dla dziejów Polaków na uchodźstwie - w słynnym Hotelu Lambert, czyli dawnej siedzibie przywódcy polskiej emigracji po Powstaniu Listopadowym, księcia Adama Jerzego Czartoryskiego. Nieco później umiejscowiono ją - jak się okazało już na stałe - w podparyskiej posiadłości Maisons-Laffitte. Tam też po spłaceniu zobowiązań finansowych wobec Drugiego Korpusu, zaczęła ona funkcjonować jako instytucja całkowicie niezależna, której jedyną zwierzchnością był - jak go określali dobrodusznie jego zwolennicy i złośliwie adwersarze - „Książę Redaktor”, lub po prostu „Redaktor”.

W ambitnym zamierzeniu samego J. Giedroycia Instytut Literacki, redakcja „Kultury” i wydawane przez nią czasopismo, miały do odegrania potrójną rolę. Po pierwsze, miały stanowić przysłowiowy okruch niepodległej Polski, emigracyjną, „eksterytorialną”, a zarazem nieformalną ambasadę sprawy polskiej. Po drugie, miały pełnić rolę aktywnego ośrodka kultury polskiej, instrumentu szerokiej promocji niezależnej polskiej literatury - to tu przecież w przyszłości mieli publikować swoje książki i artykuły wielcy emigracyjni pisarze, publicyści i poeci, m.in. Gustaw Herling-Grudziński, Józef Mackiewicz, Andrzej Bobkowski, Witold Gombrowicz, Jerzy Stempowski i Czesław Miłosz. Wreszcie - i chyba ta funkcja „Księstwa Maisons-Laffitte” była dla J. Giedroycia osobiście najważniejsza - Instytut Literacki miał stanowić ośrodek inicjujący wielkie ogólnonarodowe dyskusje o sprawach dla Polaków po II wojnie światowej najważniejszych: jak odzyskać niepodległość? Jaka będzie przyszłość Europy Wschodniej? Czy możliwa jest ewolucja komunistycznego reżimu? Jaka powinna być taktyka opozycji w kraju i polskiej emigracji? W debacie tej z założenia nie było wykluczonych. Przeciwnie - Giedroyc zmierzał do tego, aby była ona nacechowana pluralizmem ideologicznym i politycznym. Nie brakowało w niej głosów konserwatystów, piłsudczyków, liberałów, narodowców, ludowców, socjalistów i „skruszonych” komunistów, wierzących w możliwość stopniowej demokratyzacji systemu panującego za „Żelazną Kurtyną”. W dyskusji tej zabierali głos z jednej strony nieprzejednani antykomuniści, którzy nawoływali do międzynarodowej krucjaty przeciwko bolszewizmowi, z drugiej byli decydenci PRL, zrażeni do systemu, wierzący jednak $\mathrm{w}$ dalszym ciągu $\mathrm{w}$ możliwość zbudowania alternatywnego „socjalizmu z ludzką twarzą". Próbowali w jej trakcie przekonywać do swoich racji nieprzejednani niepodległościowcy, którzy traktowali PRL jako kolonię Związku Sowieckiego, a zarazem zwolennicy ,polityki drobnych kroków”, utrzymywania dialogu z reżimem, liczący na możliwość wpływania w ten sposób na 
ewolucję systemu. Wreszcie pisali do „Kultury” publicyści i politycy emigracyjni, a także krajowi - posługując się pseudonimami lub pod własnymi nazwiskami ${ }^{7}$.

Jednak zasadnicza postawa otwartości wobec dyskusji w środowisku skupionym wokół „Kultury” niejednokrotnie skutkowała spięciami pomiędzy jej uczestnikami i oskarżeniami pod adresem samego J. Giedroycia o „flirtowanie z komunistami". Tak było m.in., kiedy w październiku 1956 r. udzielił poparcia ówczesnemu nowemu I sekretarzowi Komitetu Centralnego Polskiej Zjednoczonej Partii Robotniczej, Władysławowi Gomułce, widząc w represjonowanym wcześniej przez stalinowców „Wiesławie” potencjalnego autora liberalizacji systemu. Z myślą o możliwości ewolucji ustroju PRL w kierunku przynajmniej względnej demokratyzacji nie rozstał się zresztą redaktor „Kultury” do końca istnienia PRL. Tyle tylko, że lokował swoje nadzieje we wciąż nowych postaciach i środowiskach. Kiedy upadły nadzieje na zbudowanie przez Gomułkę ,zdemokratyzowanego socjalizmu", J. Giedroyc postawił z kolei na środowisko partyjnych rewizjonistów. Nie przypadkiem to właśnie w „Kulturze” i w Instytucie Literackim ukazały się publikacje byłego najbliższego współpracownika W. Gomułki, Władysława Bieńkowskiego. To w „Kulturze” wydrukowano również głośny List otwarty do Partii autorstwa Jacka Kuronia i Karola Modzelewskiego. $\mathrm{Z}$ drugiej strony J. Giedroyc potrafił być krytyczny wobec narodowych świętości i bohaterów. Nie podobał mu się - tak dokładnie miał się wyrazić - polski papież, któremu zarzucał niedostateczne, jego zdaniem, otwarcie na dialog z prawosławiem i propagowanie postawy tradycyjnego polskiego patriotyzmu, ściśle powiązanego z katolicyzmem i nieufnego wobec wartości liberalnych. Po podpisaniu umów sierpniowych z 1980 r. krytykował „Solidarność”, dostrzegając w jej działaniach nadmierny radykalizm i nieuzasadniony optymizm w postrzeganiu rzekomej słabości reżimu PRL ${ }^{8}$.

Brak swoistej ,politycznej poprawności” J. Giedroyc demonstrował również w odniesieniu do problematyki międzynarodowej. Inaczej niż wielu polskich polityków i działaczy emigracyjnych nie ubiegał się o dotacje z amerykańskiego Komitetu Wolnej Europy. Krytykował również Rozgłośnię Polską Radia Wolna Europa za finansową zależność od Stanów Zjednoczonych. Sam zapewnił Instytutowi Literackiemu samodzielność finansową ściśle związaną z niezależnością polityczną. Już od 1954 r. nawoływał do zjednoczenia Niemiec. Głośno było w środowiskach polskiej emigracji o sprzeciwie zespołu „Kultury” wobec stanowiska polskiego rządu na uchodźstwie, który stał na stanowisku restauracji granic państwowych Rzeczypospolitej sprzed 1939 r. Natomiast gorąco popierał Giedroyc ideę przywrócenia niepodległości republikom nadbałtyckim: Litwie,

${ }^{7}$ Szerzej o „Kulturze” patrz: J. Korek, Paradoksy paryskiej „Kultury”. Styl i tradycje myślenia politycznego, Katowice 2008, passim; A.S. Kowalczyk, Giedroyc i „Kultura”, Wrocław 2000, passim.

${ }^{8}$ P. Waingertner, Jerzego Giedroycia spojrzenie na dzieje Polski i polska historiografie, „Arcana” 2012, nr 4-5, s. 245-246. 
Łotwie i Estonii oraz Białorusi i Ukrainie, widząc w restauracji suwerennego bytu tych państw gwarancję nowego stabilnego porządku w regionie Europy Wschodniej, uniemożliwiającego w przyszłości powrót sowieckiej czy rosyjskiej dominacji. O tym poglądzie Redaktora będzie jeszcze mowa w niniejszym tekście.

Po 1989 r. redaktor „Kultury” nadal szokował swymi apodyktycznymi sądami, odnoszącymi się do polskiej i międzynarodowej rzeczywistości. Otwarcie stwierdzał, iż obozowi politycznemu wywodzącemu się z dawnej „Solidarności” brakuje mężów stanu i wielkich programów politycznych. Odmówił też pryncypialnie - zaskakując zwłaszcza tych, którzy wcześniej zarzucali mu nadmierną pobłażliwość wobec komunistycznego reżimu i „konszachty” z byłymi komunistami - przyjęcia w latach dziewięćdziesiątych Orderu Orła Białego i przyjazdu do nowej Polski, motywując te decyzje faktem, iż Trzecia Rzeczpospolita nie odcięła się dostatecznie od dziedzictwa PRL. Krytykował Giedroyc ,pierwszego niekomunistycznego premiera" Tadeusza Mazowieckiego za szukanie oparcia w Związku Sowieckim przeciwko ewentualnemu niebezpieczeństwu niemieckiemu i chęć utrzymania garnizonów sowieckich w Polsce. Był pełen rezerwy wobec „planu Balcerowicza”, zarzucając ówczesnemu wicepremierowi niedostrzeganie i niedocenianie ludzkiego, socjalnego wymiaru gospodarki. W $1991 \mathrm{r}$. w korespondencji z przyjaciółmi ironicznie komentował pomysł uhonorowania go nagrodą Nobla, jaki pojawił się wśród polskiej emigracji 9 .

Warto pamiętać, że na „Kulturze” (ogółem ukazało się 637 numerów tego pisma: ostatni w październiku 2000 r., gdyż druk zakończył się - zgodnie z życzeniem J. Giedroycia - wraz z jego śmiercią) i książkach wybitnych polskich autorów - pisarzy i publicystów - ukazujących się od 1953 r. w tzw. Bibliotece „Kultury” (do 2000 r. - 511 tomów), nie zakończyła się aktywność wydawnicza Instytutu Literackiego. Od 1962 r. zainicjował on druk nowego periodyku - „Zeszytów Historycznych" ${ }^{10}$. Wydawnictwo to, poświęcone dziejom najnowszym Polski i Europy Wschodniej, przeżyło swego twórcę. Dodać jeszcze wypada, że J. Giedroyc był równocześnie członkiem kolegium redakcyjnego pisma rosyjskich dysydentów „Kontinent” oraz wchodził w skład rady redakcyjnej ukraińskiego emigracyjnego, kwartalnika „Widnowa”.

Twórca Instytutu Literackiego zmarł w nocy z 14 na 15 IX 2000 r. Do dziś dla jednych pozostaje jedną z najwybitniejszych postaci polskiej publicystyki i polityki minionego stulecia, dla drugich - publicystą o wielkich zasługach dla sprawy

\footnotetext{
${ }^{9}$ Tenże, Redaktor..., s. 59-62.

${ }^{10} \mathrm{O}$ „Zeszytach Historycznych” zob. m.in.: A.P. [A. Paczkowski], „Zeszyty Historyczne”, „Zeszyty Historyczne”, [Paryż] 1987, z. 82, s. 3-15; P. Wandycz, „Zeszyty Historyczne”, [w:] Jerzy Giedroyc. Redaktor. Polityk. Człowiek, red. i wstęp K. Pomian, Lublin 2001, s. 276-287; R. Stobiecki, Wątki historiograficzne na łamach „Zeszytów Historycznych” paryskiej „Kultury” (1962-1989), [w:] Jerzego Giedroycia rozrachunki z historia i polityka. Studia i szkice w czterdziesta rocznice „Zeszytów Historycznych”, red. S.M. Nowinowski i R. Stobiecki, Łódź 2005, s. 21-33.
} 
polskiej, ale równocześnie autorem idei z pogranicza światów politycznej rzeczywistości i fantazji ${ }^{11}$.

Spośród politycznych koncepcji J. Giedroycia i jego współpracowników - zarówno tych skupionych w Instytucie Literackim i w zespole paryskiej „Kultury", jak i wspierających pomysły jej redaktora z zewnątrz - do jednych z najistotniejszych należała idea, określana skrótem „ULB”, oparta na kilku zasadniczych postulatach: wspierania przez Polaków antysowieckich, narodowowyzwoleńczych i państwowotwórczych dążeń Litwinów, Białorusinów i Ukraińców; wypracowania z nimi politycznego porozumienia i pojednania ponad dotychczasowymi historycznymi sporami i dramatycznymi wydarzeniami; wyrzeczenia się przez Polaków rewindykacji dawnych wschodnich obszarów Rzeczypospolitej, które po zakończeniu II wojny światowej weszły w skład Litwy, Ukrainy i Białorusi; wreszcie uświadomienia Polakom, iż racją stanu ich państwa, wynikającą z konieczności skutecznej obrony przez imperializmem Rosji, jest niepodległość wschodnich sąsiadów Polski - państw Nadbałtyki (przede wszystkim Litwy), Białorusi i Ukrainy. Koncept ten należał do najbardziej hołubionych przez samego J. Giedroycia. Był przez niego traktowany jako swoisty sztandar, polityczno-intelektualny znak firmowy „Księstwa Maisons-Laffitte”, oficjalnie przez nie popularyzowany ${ }^{12}$. Tymczasem okoliczności narodzin ambitnego, geopolitycznego, giedroyciowskiego zamysłu były nader skromne. Pretekstem do dyskusji na temat pożądanej, optymalnej z punktu widzenia polskiego interesu narodowego, polityki wschodniej Rzeczypospolitej, stał się w 1952 r. list do redakcji „Kultury”, nadesłany przez jednego z czytelników. Dyskusję nad kwestią granic państwa polskiego (podważanie ich przebiegu z 1921 r. było właściwie tematem tabu w pryncypialnie w większości niepodległościowych i antysowieckich środowiskach polskiej emigracji w Wielkiej Brytanii i Stanach Zjednoczonych) J. Giedroyc zdecydował się bowiem rozpocząć po liście alumna z seminarium z Pretorii, Józefa Majewskiego, który podzielił się z redakcją „Kultury” refleksjami na temat zasadności rezygnacji przez Polaków z pretensji do dwóch kresowych historycznych miast polskich - Wilna i Lwowa ${ }^{13}$.

Dla tego pomysłu znalazł J. Giedroyc opiniotwórczych sojuszników. Gorącym adherentem i propagatorem koncepcji „ULB” stał się m.in. Józef Łobodowski - poeta, tłumacz, emigracyjny publicysta (publikował m. in. w „Kulturze” i londyńskich „Wiadomościach”) i wielki rzecznik polsko-ukraińskiego pojednania. Swój udział w popularyzowaniu idei „ULB” zaczął od prekursorskiego artykułu opublikowanego w „Kulturze” już w 1952 r. i zatytułowanego Przeciw upiorom

${ }^{11}$ O Jerzym Giedroyciu więcej w: E. Berberyusz, Ksiązę z Maisons-Laffitte, Gdańsk 1995, passim.

${ }^{12}$ A. Stępnik, Ukraina, Litwa i Białoruś w ,Zeszytach Historycznych” (1962-1991), [w:] Jerzego Giedroycia rozrachunki..., s. 61.

${ }^{13}$ A. S. Kowalczyk, Rzeczpospolita epistolarna, [w:] J. Giedroyc, J. Stempowski, Listy 1946-1969, wybór, wstęp, przypisy A.S. Kowalczyk, Warszawa 1998, cz. 1, s. 7. 
przeszłości. Zawierał on konstatację, że niepodległość Ukrainy leży w żywotnym interesie Polski, podobnie jak bliska współpraca polityczna ukraińsko-polska. Apelował też:

Czas byłby najwyższy, aby Polacy zrozumieli, że Ukraińcy są odrębnym narodem o takim samym prawie do samoistności, jakie przysługuje każdemu narodowi. Że wiele cech ujemnych, które nas rażą, albo się nam dotkliwie we znaki, powstało na skutek tragicznej historii i nienormalnego rozwoju kultury narodowej, stale skrępowanej przez nieprzyjazne okoliczności ${ }^{14}$.

Zainicjowana w środowisku samej „Kultury” i wśród czytelników pisma debata nad stosunkiem do przyszłości dawnych polskich Kresów Wschodnich; na tym tle - nad ewentualnym porozumieniem ze wschodnimi sąsiadami Polski; wreszcie - nad potrzebą wspierania ich ambicji niepodległościowych, nabrała rumieńców w początkach lat sześćdziesiątych. W głośnym artykule z 1962 r. na łamach „Kultury”, pt. Na ruinach przedmurza, polityczny przyjaciel J. Giedroycia, emigracyjny pisarz i publicysta, Juliusz Mieroszewski, zadeklarował:

Pragnąc dopomóc narodom Związku Sowieckiego w wydobyciu się z izolacji, musimy sami wyjść z izolatora naszych wielowiekowych tradycji1 ${ }^{15}$.

Przekonywał, że idea Polski jako ,przedmurza” cywilizacji zachodniej winna być definitywnie porzucona i zastąpiona koncepcją odgrywania przez Rzeczpospolitą Polski roli „pomostu” między narodami Związku Sowieckiego, a Europą Zachodnią - której to argumentacji gorąco sekundował Redaktor ${ }^{16}$.

On sam z Polski niepodległej przed 1939 r. wyniósł przemożne przeświadczenie o potrzebie naprawy stosunków z narodami litewskim, ukraińskim i białoruskim. Pojednanie to miało wytworzyć w przyszłości zupełnie nową konfigurację w Europie Wschodniej - sprawić, że państwo sowieckie ulegnie stopniowemu rozchwianiu. „ULB” nie było przy tym - jak podkreślał wielokrotnie J. Giedroyc - koncepcją idealistyczną, lecz opartą na chłodnym politycznym rozumowaniu; zdroworozsąakowej kalkulacji, pozbawionej emocji; wreszcie na solidnych podstawach wyrachowanej „realpolitik”. Twórca „Kultury” wiedział, że wśród Litwinów, Białorusinów i Ukraińców żywe są antypolskie resentymenty, a wśród Polaków zwłaszcza antyukraińskie i do pewnego stopnia antylitewskie. Ale w imię geopolityki - ponad emocjami - narody te miała łączyć obiektywnie wspólnota losów, którą ich elity powinny właściwie odczytać i zinterpretować ${ }^{17}$.

${ }^{14}$ J. Łobodowski, Przeciw upiorom przeszłości, „Kultura”, [Paryż] 1952, nr 2-3, s. 46.

${ }^{15}$ J. Mieroszewski, Na ruinach przedmurza, „Kultura”, [Paryż] 1962, nr 5, s. 108.

${ }^{16}$ J. Giedroyc, Przestanie, [w:] tenże, Autobiografia na cztery..., s. 227-228.

${ }^{17}$ M. Kornat, Jerzy Giedroyc a polska myśl polityczna XX stulecia, „Zeszyty Historyczne”, [Paryż] 2010, t. 55, s. 62. 
Jerzy Giedroyc był przekonany, że z doświadczeń IV rozbioru Polski, dokonanego w 1939 r. przez hitlerowskie, narodowosocjalistyczne Niemcy i komunistyczną Rosję Stalina oraz porozumień mocarstw w Jałcie należy wyciągnąć dalekosiężne i brzemienne w konsekwencje wnioski. Zakładał, że strategiczne sojusze z mocarstwami zachodnimi nie mogą i nie są w stanie zastąpić racjonalnego, osiągniętego $\mathrm{w}$ imię fundamentalnej wspólnoty interesów, porozumienia Polski z sąsiadami na wschodzie. Domagał się, w związku z tym, aby Polacy na nowo zdefiniowali i zbudowali stosunki z tymi narodami, co miało pomóc w uzyskaniu i utrzymaniu przez Rzeczpospolitą suwerenności „w przeciągu historii”, „W miejscu otwartym na wszystkie wiatry historii” ${ }^{18}$ - pomiędzy Rosją i Niemcami. Redaktor przekonywał, iż normalizacja stosunków z Ukraińcami, Białorusinami i Litwinami stanowi podstawowy warunek utrzymania niepodległości Polski. Obawiał się ponadto, że próby kontynuowania przedwojennej polityki wschodniej mogą przynieść Polsce konflikt interesów z Niemcami, które zjednoczą się w przyszłości i zostaną europejskim mocarstwem. Jeśli Polacy wówczas nie uznają „Wilna litewskiego" i „Lwowa ukraińskiego” to narody te zwrócą się do Niemiec, jako politycznego patrona. Absurdem byłoby wówczas - zdaniem J. Giedroycia - szukanie na demokratycznym Zachodzie poparcia dla polskich rewindykacji terytorialnych $\mathrm{w}$ regionie.

Twórca Instytutu Literackiego argumentował przy tym, iż silniejsza pozycja Polski na wschodzie będzie skutkować mocnym stanowiskiem wobec państw zachodnioeuropejskich i poparciem z ich strony polskiej polityki wobec Rosji. Konstatowal:

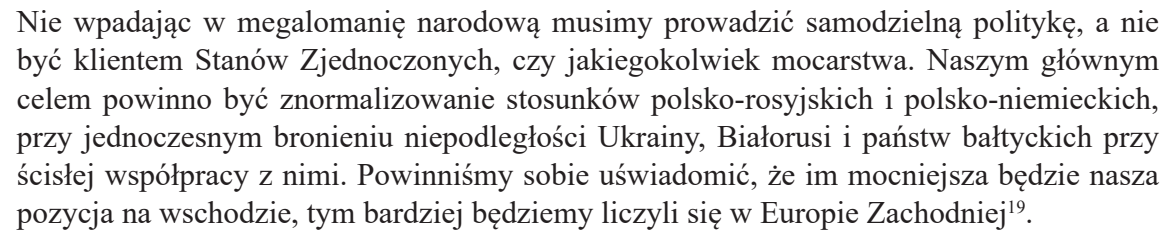

Redaktor przestrzegał równocześnie, iż porozumienia z Ukrainą, Litwą i Białorusią nie powinno się traktować jako instrumentu dla stosowania prostego szantażu wobec Rosji. Tego rodzaju manipulacja kryłaby w sobie bowiem gotowość porzucenia sojuszu z Ukrainą za cenę porozumienia z Moskwą - która wszak nigdy nie widziała w Polsce równorzędnego partnera.

${ }^{18}$ J. Pomorski, Jerzego Giedroycia rozumienie historii, [w:] Jerzego Giedroycia rozrachunki..., s. 13.

${ }^{19}$ J. Giedroyc, Autobiografia na cztery..., s. 228. Na ten temat zob. też: E. Rybałt, Od normalizacji do strategicznego partnerstwa. Przyczynek do problemu stosunków polsko-ukraińskich w myśli politycznej Jerzego Giedroycia, [w:] Jerzego Giedroycia rozrachunki..., s. 69-80; A. Stępnik, Ukraina, Litwa ..., s. 51-68. 
Koncepcja „ULB”, propagowana przez J. Mieroszewskiego i J. Giedroycia wyrastała ze zmodernizowanych wizji federacyjnych, formułowanych wcześniej przez tego pierwszego, ufundowanych na ideach przyświecających kilka dekad wcześniej Naczelnikowi Państwa, Józefowi Piłsudskiemu, zakładających zbudowanie w przyszłości regionalnego związku państw Europy Środkowo-Wschodniej. Zyskała ona orędownika w postaci J. Giedroycia, ponieważ centralną rolę w tym programie odgrywała „kwestia ukraińska”, którą ten uważał za jedną z najważniejszych dla przyszłości Polski.

Zarówno J. Giedroyc, jak i J. Mieroszewski traktowali przy tym ideę „ULB” jako najwłaściwszą po niepowodzeniu „koncepcji jagiellońskiej” J. Piłsudskiego - odrzucanej zarazem jako wyraz polskiego imperializmu przez Ukraińców, Litwinów i Białorusinów. Zaniechanie jej realizacji nie oznaczało dla J. Giedroycia i J. Mieroszewskiego przekreślenia szerszego konceptu „drogi jagiellońskiej”, rozumianej jako perspektywiczne współdziałanie z wschodnimi sąsiadami. Tym niemniej obydwaj zdawali sobie sprawę z konieczności przezwyciężenia ich sceptycyzmu wobec polskich inicjatyw integracyjnych:

„Idea Jagiellońska” - pisał J. Mieroszewski - tylko dla nas nie ma nic wspólnego z imperializmem. Jednak dla Litwinów, Ukraińców i Białorusinów stanowi najczystszą formę polskiego tradycyjnego imperializmu. Rzeczpospolita Obojga Narodów zakończyła się całkowitym spolonizowaniem szlachty litewskiej i najgorętsze wyznanie miłości do Litwy („Litwo, ojczyzno moja, Ty jesteś jak zdrowie”) zostało napisane w języku polskim. Polak nie może sobie nawet wyobrazić podobnej sytuacji. Czy można sobie wyobrazić Słowackiego piszącego wyłącznie po rosyjsku [...]? Przyjemnie jest sobie powiedzieć, że kultura polska jest atrakcyjna - dla wielu nawet bardziej atrakcyjna niż rosyjska, lecz ten sam fakt oceniany z perspektywy litewskiej czy ukraińskiej oznacza, że Polacy są groźniejszymi asymilatorami niż Rosjanie. Trzeba tylko odpowiedniej koniunktury, by Polacy mogli w pełni rozwinąć swoje asymilatorskie skrzydła ${ }^{20}$.

Argumentacji J. Mieroszewskiego wtórował Redaktor, przedstawiając zarazem rozwiązanie problematu stosunków pomiędzy Rzeczpospolitą, a Litwą, Białorusią i Ukrainą:

Idea jagiellońska jest niewątpliwie dziś tromtadracją i ostatnia szansa prometeizmu skończyła się wraz z traktatem ryskim. Sprawa Lwowa i Wilna jest dla nas sprawa przesądzoną. Nie można jednakowoż ograniczyć się jedynie do koncepcji endeckiej państwa etnograficznego [...]. Możliwości i obowiązki połączenia naszych starań o odzyskanie niepodległości z pomocą i oddziaływaniem na Białoruś, Ukrainę, Litwę [...] jest to koncepcja realna ${ }^{21}$.

${ }^{20}$ J. Mieroszewski, Rosyjski kompleks polski i obszar ULB, ,Kultura”, [Paryż] 1974, nr 9, s. 3-14.

${ }^{21}$ J. Giedroyc, J. Stempowski, Listy 1946-1969 ..., Warszawa 1998, cz. 2, s. 208. List J. Giedroycia do J. Stempowskiego z 6 X 1962 r. 
Kiedy indziej zaś stwierdzał:

Ma się rozumieć, koncepcja jagiellońska jest dziś rzeczą przebrzmiałą i ma wydźwięk uczuciowy jedynie dla tych, którzy się urodzili w Polsce jagiellońskiej [...]. W Kijowie [...] młoda inteligencja jest zapatrzona na Polskę i Warszawa dla niej odgrywa rolę Paryża. To już się kończy, bo wszystkie awanse z ich strony spotykają się z zimna pogardą i obojętnością ze strony polskiej. Jest to połączone z dużą dozą tchórzostwa i oportunizmu, bo przecież wiadomo, że na te sprawy Moskwa patrzy bardzo krzywym okiem [...]. Naszym zadaniem jest normalizacja stosunków polsko-ukraińskich, potraktowanie obecnej granicy jako sprawy przesądzonej oraz (co jest najtrudniejsze) dyskretne popieranie tendencji do uniezależniania się poszczególnych narodów Związku Sowieckiego, bez tracenia wpływu i normalizacji stosunków ze społeczeństwem rosyjskim ${ }^{22}$.

Podstawą zaproponowanej przez J. Giedroycia i J. Mieroszewskiego koncepcji polskiej polityki wschodniej - opartej na pomyśle współpracy z niepodległościowymi siłami litewskimi, białoruskimi i ukraińskimi w celu osłabienia potęgi Związku Sowieckiego - miała być zatem na nowo zdefiniowana pamięć historyczna: nie polskiej dominacji i hegemonii, ale partnerskiej kooperacji ponad przepracowanymi historycznymi podziałami ${ }^{23}$.

Właściwymi torami dla dziejów Polski była dla J. Giedroycia, jak już wspomniano, tzw. droga jagiellońska - nie jako rewitalizowany wciąż na nowo anachronizm, ale jako aktualne, nowoczesne wyzwanie; rozumiana nie w kategoriach cywilizacyjnej i terytorialnej ekspansji na wschód, ale rozumnej polityki kształtowania regionu wspólnie z najbliższymi sąsiadami: niegdyś z „wielką Litwą”, w okresie międzywojnia z republikami nadbałtyckimi, w przyszłości z niepodległymi (w co gorąco wierzył) Litwą, Łotwą, Estonią, Białorusią i Ukrainą; wreszcie w stosunkach wewnętrznych pojmowana jako ciągłe praktykowanie postaw tolerancji narodowościowej i wyznaniowej - dla „polskich” Litwinów, Białorusinów i Ukraińców, dla „polskich” prawosławnych i grekokatolików. Twórca Instytutu Literackiego deklarował:

Przede wszystkim powinniśmy zmienić mentalność narodu. Wymaga to [...] poszanowania praw naszych mniejszości narodowych; musimy pamiętać, że jest to warunkiem dobrych stosunków z sąsiadami. Zdając sobie sprawę, że katolicyzm jest wyznaniem znakomitej większości narodu, musimy dbać również o Żydów, mahometan i protestantów oraz o prawosławie, które jest wyznaniem panującym w Rosji, na Ukrainie, na Białorusi ${ }^{24}$.

Postulatowi dialogu, prowadzonego w duchu poszanowania odrębności narodowych i religijnych z zamieszkującymi w Polsce Ukraińcami, Litwinami i Białorusinami, towarzyszyła refleksja i praktyka działania środowiska „Kultury”,

${ }^{22}$ J. Giedroyc, J. Stempowski, Listy 1946-1969 ..., cz. 2, s. 336. List J. Giedroycia do J. Stempowskiego z 4 X 1965 r.

${ }^{23}$ J. Mieroszewski, O międzynarodowa brygadę europejska, „Kultura”, [Paryż] 1951, nr 11, s. 79.

${ }^{24}$ J. Giedroyc, Autobiografia na cztery..., s. 245-247; P. Waingertner, Jerzego Giedroycia spojrzenie..., s. 249. 
nakierowana na porozumienie z ukraińską - często antypolsko nastawioną - emigracją.

Udało mi się ustalić konieczność naukowego i obiektywnego przepracowania dwóch tematów: stosunki polsko-ukraińskie w czasie dwudziestolecia oraz stosunki polsko-ukraińskie w czasie ostatniej wojny - stwierdzał J. Giedroyc ${ }^{25}$.

Redaktor „Kultury” nie unikał przy tym wobec Ukraińców posunięć wręcz prowokacyjnych dla wielu współczesnych mu Polaków, pamiętających o podejmowanych przez Ukraińcach próbach współpracy z Trzecią Rzeszą w latach II wojny światowej i tzw. rzezi wołyńskiej z 1943 r. $^{26}$

Otóż, czy nie byłyby możliwości, by Bandera ${ }^{27}$ dał artykuł lub wywiad dla „Kultury”, precyzujący jego stosunek do Polski i wspólnej walki z Sowietami? [...]. Zdaję sobie sprawę, jak w środowisku ukraińskim jest trudno poruszać tematykę polską względnie obiektywnie na skutek terroru opinii jeszcze większego niż u nas, ale normalnie skrajni nacjonaliści i dyktatorzy zdobywają się łatwiej na tego rodzaju posunięcia - pisał do J. Stempowskiego w 1950 r. $^{28}$

Z koncepcją „ULB” wiązał J. Giedroyc tzw. kwestię rosyjską. Stanowisko „Kultury” wobec polityki „na kierunku rosyjskim” ewoluowało. Ostatecznie J. Mieroszewski, wspierany przez J. Giedroycia, doszedł do wniosku, że jedynym sensownym antysowietyzmem jest działanie na rzecz demokratyzacji Związku Sowieckiego. Odrzucał zdecydowanie emigracyjny antykomunizm przechodzący, według niego, w nieuzasadnioną rusofobię - interpretując te idee, jako pozbawione wymiaru moralnego, generujące jałową nienawiść do Rosji. Zdaniem J. Mieroszewskiego w przyszłości demokratyczna Rosja i niepodległa Polska miałyby realną szansę pokojowego ułożenia i uporządkowania wzajemnych stosunków. Uważał przy tym, że racją nadrzędną obu państw jest przyznanie pełnej niepodległości krajom „ULB”, których nie można traktować jedynie jak pionków

${ }^{25}$ J. Giedroyc, J. Stempowski, Listy 1946-1969..., cz. 2, s. 337. List J. Giedroycia do J. Stempowskiego z 4 X 1965 r.

${ }^{26}$ Rzeź wołyńska - masowa zbrodnia (czystka etniczna), dokonana przez nacjonalistów ukraińskich niekiedy przy wsparciu miejscowej ludności ukraińskiej na mniejszości polskiej na terenie byłego województwa wołyńskiego Drugiej Rzeczypospolitej (w czasie wojny pozostającego w granicach Komisariatu Rzeszy Ukraina), w okresie od lutego 1943 r. do lutego 1944 r. Ofiarami mordów, których kulminacja nastąpiła w lecie 1943, byli Polacy, w dużo mniejszej skali Rosjanie, sami Ukraińcy (ugodowo nastawieni wobec polskich sąsiadów), Żydzi, Ormianie, Czesi i przedstawiciele innych narodowości zamieszkujących Wołyń. Nie jest znana dokładna liczba ofiar, historycy szacują, że zginęło ok. 50-60 tys. Polaków.

${ }^{27}$ Stepan Bandera (1909-1959) - ukraiński polityk niepodległościowy o poglądach nacjonalistycznych, jeden z przywódców i ideologów Organizacji Ukraińskich Nacjonalistów, w latach II wojny światowej zwolennik współpracy Ukraińców z Niemcami i budowy państwa ukraińskiego w oparciu o Trzecią Rzeszę, więzień niemieckich obozów koncentracyjnych, po II wojnie światowej jeden z liderów emigracji ukraińskiej, zamordowany w Monachium przez sowieckiego agenta.

${ }^{28}$ J. Giedroyc, J. Stempowski, Listy 1946-1969..., cz. 1, s. 105. List J. Giedroycia do J. Stempowskiego z 9 V $1950 \mathrm{r}$. 
w wielkiej polsko-rosyjskiej regionalnej grze politycznej. Podkreślał, że polityka trwałej suwerenności regionu „ULB”, ale i jego otwarcia na zachód i na wschód zakończy polsko-rosyjską rywalizację na historycznym wschodzie Polski.

Z poglądami J. Mieroszewskiego na „kwestię rosyjską” zgadzał się w pełni Redaktor. Wysiłki swoje i środowiska „Kultury” w tej sferze podsumowywał w sposób następujący:

W moim przekonaniu głównym celem „Kultury” jest utrzymanie roli i znaczenia Polski w Europie Wschodniej [...]. Dążenie do uczynienia w przyszłości z Polski swego rodzaju zwornika w tej części Europy. Wymagało to w pierwszym rzędzie oczyszczenia przedpola - a więc niedwuznaczne postawienie sprawy Wilna i Lwowa jako niezbędnego warunku normalizacji stosunków z Ukraina i Litwą. Ustalenie, że walczymy z ustrojem sowieckim, ale dążymy do normalizacji stosunków z Rosją i nawiązania współpracy z inteligencja rosyjską [...]. To dało pewne rezultaty: dysydenci wiedzą o „Kulturze” i znają ją, są nawet ośrodki specjalnie uczące się polskiego, by móc ja czytać (dociera do Rosji różnymi drogami ok. 100 egz.). $Z$ chwila zjawienia się na Zachodzie nowej emigracji rosyjskiej nawiązała ona z miejsca bliski z nami kontakt. Z inicjatywy Sołżenicyna byliśmy w pewnej mierze współzałożycielami „Kontinentu” i kilka osób z „Kultury” weszło do jego redakcji ${ }^{29}$. Za największy sukces, mający chyba znaczenie historyczne, uważam uzyskanie deklaracji czołowych dysydentów rosyjskich, uznających zasadę niepodległości dla Ukrainy i innych nierosyjskich republik związkowych. Jeśli idzie o Ukrainę, to w dużej mierze udało się przełamać wrogie nastroje i tu także nastąpiła współpraca ${ }^{30}$.

W stosunku do Związku Sowieckiego propagował J. Giedroyc strategię ewolucjonizmu. Nie wierzył, że wojna położy kres sowieckiej potędze. Natomiast myślał o stopniowej emancypacji narodów ZSRS na skutek wewnętrznej ewolucji i presji Zachodu.

Swoistym podsumowaniem dziejów idei „ULB” (również w kontekście stosunków polsko-rosyjskich) i jej znaczenia dla samego J. Giedroycia może być ocena współpracującego z nim przez długie lata emigracyjnego intelektualisty, eseisty, publicysty i krytyka, Konstantego Jeleńskiego:

Giedroyc w czerwcu 1980 roku [...] wymienił jako najważniejsze osiągnięcia „Kultury” jej walkę o normalizację stosunków Polski z „ULB” (termin ukuty przez J. Mieroszewskiego dla określenia krajów należących do dawnego Wielkiego Xięstwa Litewskiego: Ukrainy, Litwy, Białorusi) i jej wysiłki dla przeprowadzenia rozróżnienia pomiędzy ZSSR (jego ustrojem i imperialną polityką) a Rosją. Zasługa „Kultury”, polegająca na przeciwstawieniu się, od samego początku, tak w Polsce rozpowszechnionej nienawiści do Rosji, jest tym większa, że na sześć osób, które stanowiły u zarania najściślejszy zespół pisma, cztery były deportowane do ZSSR po aneksji wschodniej części kraju: Józef Czapski, Gustaw Herling-Grudziński, Zofia i Zygmunt Hertz [...]. Stosunki polsko-rosyjskie i przyszłość narodów żyjących między tymi dwoma państwami są zresztą dla redaktora „Kultury” od siebie nieodłączne ${ }^{31}$.

${ }^{29}$ Do redakcji „Kontinentu” zostali zaproszeni m.in.: Józef Czapski, Jerzy Giedroyc i Gustaw Herling-Grudziński.

${ }^{30}$ J. Giedroyc, K.A. Jeleński, Listy 1950-1987, wybór, oprac., wstęp W. Karpiński, Warszawa 1995, s. 433-434. List J. Giedroycia do K. Jeleńskiego z 9 VI 1980 r.

${ }^{31}$ K. Jeleński, O „Kulturze” dla Francuzów..., s. 493. 
Z kolei historyk Marek Kornat podkreśla:

Z lekcji Giedroycia dla Polaków pozostaje nam fundamentalna teza, że niezawisłość polityczna narodu litewskiego, ukraińskiego i białoruskiego jest wielką sprawa w interesie Polski, bowiem stwarza nowy ład w Europie Wschodniej i pozbawia Rosję imperium, a przez to otwiera przed polityką polską nowe możliwości. Doktrynę „ULB” uznaje się słusznie za najważniejsze osiągnięcie myśli politycznej J. Giedroycia i J. Mieroszewskiego. Mimo wszystkich uwikłań w stosunkach Polski z jej wschodnimi sąsiadami, nie utraciła ona aktualności ${ }^{32}$.

Dziejopis zauważa też:

Wizja Giedroycia kultury polskiej jako czynnika pośredniczącego we wzajemnych stosunkach narodów Europy Środkowo-Wschodniej. Pełnienie tej roli przez Polskę jest uzależnione od dobrych stosunków polsko-rosyjskich. Po 1989 r. Giedroyc zdawał się wierzyć, iż poprawa tych stosunków jest możliwa przy umacnianiu partnerstwa $\mathrm{z}$ innymi narodami niepodległymi dawnego ZSRR ${ }^{33}$.

Zdaniem J. Giedroycia rozwój współpracy Polski z całym obszarem ULB powinien stanowić priorytet nowej polityki wschodniej. Współpraca taka wzmacniałaby cały ten obszar wobec Rosji, zapobiegając odbudowaniu jej dominującej pozycji po ewentualnym rozpadzie imperium. Z kolei według J. Mieroszewskiego teren ULB miał być czymś więcej niż przysłowiową „kością niezgody”, terenem rywalizacji między Polską a Rosją. Przekonywał też czytelników „Kultury”, że dążenie Polaków do zrzucenia moskiewskiej kurateli powinno uwzględniać jeszcze gorszy los Litwinów i Ukraińców. Wywołało to w polskim środowisku uchodźczym gwałtowne polemiki. „Kultura” została odsądzona przez część antylitewsko i antyukraińsko nastawionych polskich emigrantów od czci i wiary. Tymczasem J. Giedroyc konsekwentnie na łamach swojego pisma przekonywał rodaków z emigracji, że trwanie przy idei zachowania Kresów dla Rzeczypospolitej i na stanowisku wrogości wobec wschodnich sąsiadów, uniemożliwia Polakom zjednywanie potencjalnych sprzymierzeńców. Długofalowe cele strategiczne Polski wymagały, według niego, cierpliwego pozyskiwania zwolenników za naszą wschodnią granicą.

Czy idea „ULB”, której instrumentem realizacji miało być początkowo porozumienie i współpraca opiniotwórczych elit intelektualnych i politycznych Europy Wschodniej, mających wpływać na postawy całych narodów, powiązana początkowo - zgodnie z intencjami jej propagatorów, przede wszystkim J. Giedroycia i J. Mieroszewskiego, ale także licznych członków i współpracowników zespołu „Kultury” - z dążeniem do osłabienia dominacji Rosji (jako hegemona w Związku Sowieckim) nad wschodnioeuropejskimi nacjami, pozostającymi w granicach państwa sowieckiego oraz intencją wpływania na liberalizację stosunków

\footnotetext{
${ }^{32}$ M. Kornat, Jerzy Giedroyc a polska ..., s. 65.

${ }^{33}$ Tamże, s. 66-67.
} 
wewnętrznych w ZSRS; następnie - w ostatniej dekadzie XX w. - z realizacją idei ścisłej współpracy pomiędzy Polską, Litwą, Białorusią i Ukrainą (zarówno na poziomie państwowym, jak i obywatelskich społeczeństw) oraz ustanowieniem dobrosąsiedzkich stosunków z nową, demokratyczną Rosją, okazała się realistycznym programem politycznym, czy też utopijną idée-fixe Redaktora i grupy jego adherentów?

Udzielenie odpowiedzi na to pytanie nie jest proste. Uwzględnić w niej trzeba zarówno realizm diagnoz i recept oraz skuteczność podejmowanych działań w dwóch okresach historycznych (pomiędzy którymi cezurę stanowi początek lat dziewięćdziesiątych minionego stulecia, kiedy to następuje ekonomiczny krach komunizmu, rozpad Bloku Wschodniego i Związku Sowieckiego, a także odzyskanie pełnej suwerenności przez państwa tzw. demokracji ludowej oraz republiki nadbałtyckie, Białoruś i Ukrainę), jak i przynajmniej trzy aspekty koncepcji: kwestię relacji pomiędzy Polską i Nabdbałtyką, Białorusią i Ukrainą (najpierw ich elitami, narodami, wreszcie samymi państwami); zagadnienie znaczenia tych relacji dla pozycji Polski w integrującej się Europie; wreszcie „kwestię rosyjską” - stanowiące najważniejsze punkty w ,giedroyciowskim” programie „ULB”.

W okresie pierwszym i drugim założenia koncepcji „ULB” i działania podejmowane dla jej realizacji w zakresie dwóch pierwszych aspektów należy, moim zdaniem, ocenić jako zgodne z wymogami racjonalnej polityki i dalekowzroczne - stawiające ich twórców i propagatorów w szeregu prawdziwych politycznych „statystów”. Jednakże działania podejmowane dla pojednania Polaków z Litwinami, Białorusinami i Ukraińcami na poziomie elit, czy społeczeństw miały rzecz jasna znaczenie przede wszystkim dla budowania perspektyw dla porozumienia narodów, przyszłej współpracy międzypaństwowej po upadku Związku Sowieckiego i wzmocnienia ich wspólnej pozycji w Europie (pomimo występujących przecież nadal pomiędzy nimi konfliktów i uprzedzeń) - w mniejszym stopniu dla samego procesu demontażu i upadku państwa sowieckiego, o których zadecydowały niewydolność ekonomiczna komunizmu i polityka wybitnych przywódców „Wolnego Świata” doby rewolucji konserwatywnej lat osiemdziesiątych, a przede wszystkim prezydenta Stanów Zjednoczonych Ronalda Reagana.

Z kolei rachuby J. Giedroycia i jego zwolenników uwzględniających w ramach projektu „ULB” także skuteczne oddziaływanie na rosyjskie elity (a przez nie na społeczeństwo i państwo) w kierunku demokratyzacji i liberalizacji myślenia Rosjan zarówno o ustroju Rosji - relacjach: władza-obywatel - jak i jej roli w Europie przyszłość zweryfikowała negatywnie.

Wizerunek mentalny i polityczny współczesnej Rosji zdaje się bowiem potwierdzać pesymistyczne diagnozy, głoszące, iż tak jak współczesna Rosja nie jest demokracją, lecz w istocie reżimem dyktatorskim, tak spójna $\mathrm{z}$ nim wydaje się mentalność Rosjan - nie demokratyczna, liberalna i indywidualistyczna, ufundowana na wartościach zachodniej cywilizacji łacińsko-anglosaskiej, ale 
autorytarna, wspólnotowa, wywodząca się z tradycji orientalnych, azjatyckich. Ze spójności tej wynika wywołujący konfuzję części polityków i ekspertów pozorny paradoks masowego poparcia, udzielanego przez „ciemiężonych” Rosjan „ciemiężącemu” ich „tyranowi”. W myśl tej diagnozy Rosjanie akceptują władzę silną - nawet brutalną i bezwzględną - ale skuteczną, legitymizującą się sukcesami, wykazującą wobec rządzonych postawę patrona i opiekuna, ostatecznej instancji odwoławczej. Taki model relacji pomiędzy rządzącymi i rządzonymi miały uwarunkować historycznie - zdaniem sceptycznie zapatrujących się na perspektywy „europeizacji” Rosji - panowanie najeźdźców ze Skandynawii, czyli twórców państwa ruskiego, okrutne rządy Mongołów, „upaństwowione” prawosławie wspierające idee omnipotentnego władcy i absolutnego poddaństwa ludu, samodzierżawie dobrego „Cara-Ojca Narodu”, wreszcie totalitarny komunizm. Taki model relacji rosyjscy przywódcy przenieśli zaś do polityki zagranicznej, czyniąc to zarówno wierni metodom, sprawdzonym w relacjach wewnątrzrosyjskich, jak i dążąc do wzmocnienia swej pozycji w kraju (którego obywatele rekompensują sobie materialną mizerię świadomością bycia mieszkańcami mocarstwa) poprzez ogłaszanie kolejnych międzynarodowych triumfów.

Podsumowując, rola „europejskiego pomostu na wschód” (nie zaś „europejskiego przedmurza"), jaką Giedroyc przeznaczał Polsce okazała się trafna jedynie w perspektywie ograniczonej do Nadbałtyki, Białorusi i Ukrainy. Wydaje się, iż regionowi „ULB” - zakładając nawet dobrą wolę jego politycznych liderów, którzy wszak płacąc cenę za pozyskanie do współpracy Rosji nie mogą przekroczyć granicy, jaką jest poświęcenie na ołtarzu porozumienia z Kremlem żywotnych interesów własnych państw i narodów - nadal przeznaczone jest odgrywanie roli znanej z historii: cywilizacyjnego przedmurza definiowanej w kategoriach cywilizacyjnych Europy i wspólnoty transatlantyckiej. 
Przemystaw Waingertner

\section{JERZY GIEDROYC'S ULB IDEA - GENESIS, PREMISES, ATTEMPTS OF IMPLEMENTATION. OUTLLINE OD ISSUES}

Jerzy Giedroyc (1906-2000), in the Second Republic of Poland the ministerial official and, above all, ideologue and leader of the student youth organization of the conservative movement and the originator neo-conservative periodical "Bunt Młodych" and "Polityka", in the years of World War II in the Second Polish Corps, is known above all as one of the most important figures of Polish emigration after the World War II - organizer of the Literary Institute in Paris, creator of the periodicals "Kultura" and "Zeszyty Historyczne" and the publisher of the greatest writers of Polish emigration. Along with his political allies and associates (Juliusz Mieroszewski, Józef Łobodowski, Konstanty Jeleński and Jerzy Stempowski) became famous as the creator and promoter of the idea of "ULB" - historic reconciliation and cooperation between the Poles, Lithuanians, Ukrainians and the Belarussians, the aim of which was to be the weakening of the Soviet domination of Eastern Europe and creating of the grounds for close co-operation of Ukraine, Lithuania and Belarus with Poland after the fall of the Soviet Union. It would be the guarantee stability in the region, the antidote to the revival of Russian imperialism, as well as a pillar of the position of the states of "ULB" in Europe. 